\title{
Raising a New Generation of Professionals: Revising the Principles of Teaching Foreign Languages to Non-Linguistic University Students
}

\author{
Anastasia Ananyina \\ Chair of Foreign Languages for Students of Humanities \\ Petrozavodsk State University \\ Petrozavodsk, Russia \\ ananyinastya@yahoo.com \\ Elena Makarova \\ Business Foreign Languages Department \\ Ural State University of Economics \\ Ekaterinburg, Russia
}

\author{
Irina Abramova \\ Chair of Foreign Languages for Students of Humanities \\ Petrozavodsk State University \\ Petrozavodsk, Russia \\ Elena Shishmolina \\ Chair of Foreign Languages for Students of Humanities \\ Petrozavodsk State University \\ Petrozavodsk, Russia
}

\begin{abstract}
Current global economic processes bring into focus strengthening international cooperation, developing transparent partnerships, and establishing professional exchange. This leads to the necessity to narrow the gap between higher professional education and the requirements of business and economic environment. National educational models need to intensify the shift from knowledge-based teaching to developing truly competitive competences, with special focus on foreign language communicative competence. This paper presents the results of teaching quasi-professional group communication in English to the students of non-linguistic university majors. The aim of the research was to analyze the experience of forming soft skills and educational competence through English language communication between the students of economy and international relations from two Russian state universities. The authors used the method of comparative analysis of formal structured survey results, and the methods of statistical data processing. The preliminary survey revealed that the respondents suffered from foreign language anxiety, were not ready to communicate with many people at once, and preferred free discussions to regulated professionally valuable polylogue. In order to overcome the communication barriers the authors designed and tested an experimental alternative teaching methodology. The preliminary research results lead to the conclusion that raising a new generation of professionals with soft skills and educational competence required by the new Russian economy is hardly possible without extending the range of teaching tools and changing approaches to teaching nonlinguistic university students how to use a foreign language for professional communication.
\end{abstract}

Keywords: knowledge-driven economy, human capital, soft skills, educational competence, communicative competence, professional communication, polylogue, diverse professional environment

\section{INTRODUCTION}

Current global economic processes increasingly bring into focus such principles as strengthening international cooperation, developing transparent and mutually beneficial partnerships, and establishing cultural and people-to-people exchange, which enhances understanding and trust among multi-ethnic and multi-cultural communities of professionals. High efficiency of such collaborations is supported by the results of the recent studies [1, 2, 3]. Global innovative economic projects significantly affect human resource development in various regions and countries. This emphasizes the necessity to develop the competitive advantages of the regions which have potential for global economic interaction. Therefore, many economic sectors urgently need qualified employees ready and willing to adjust to new digital business environment and learn throughout life. «Improvement of professional competences of a specialist of the 21 st century in any field of activity and development of social communication skills are connected with the necessity of constant obtaining and updating of knowledge» [4]. In the future, economic and business success will to a large extent depend on international collaborations, which will require training a new generation of professionals with a strong focus on soft and communication skills.

All this leads to the necessity to narrow the gap between the requirements of today's business and economic environment and higher professional education. National educational models need to intensify the shift from 
knowledge-based teaching to developing truly competitive competences, with special focus on foreign language communicative competence which ensures effective interpersonal, professional and business communication in multinational teams. This paper presents the results of using certain experimental forms of teaching quasi-professional group communication in the English language to the students of non-linguistic university majors. The aim of the study was to analyze the experience of forming soft skills and educational competence through English language communication between the students of economy and international relations from two state universities operating in different regions of the Russian Federation.

\section{LITERATURE REVIEW}

Both Russian and foreign university teachers of foreign languages follow the developments of the current market and try to adjust the teaching methods and techniques accordingly. Rus and Medrea in their article "Developing communicational abilities in professional environments through English language teaching" wrote, "Students and teaching staff alike are highly aware of the asset that good communication skills represent in the conditions of the contemporary world. Inevitably, the English knowledge is a must in this equation: responsible for this is the highly globalized economy, the emergence of English as the lingua franca of the technical discourse and also the opening of the labor market outside the confines of the national territory" [5].

More specifically, experts emphasize the importance of teaching English communication skills to people who will end up working in teams as members of international collaborations. An interesting insight into the matter is given in the article «Good, better, best: English language development practices in graduate business programs» written by Andrade, Hartshorn, Evans and Davis [8]. They analyze whether the international students of business schools in the USA, Britain, Canada and Australia are "adequately equipped with the language skills they need to succeed". The authors point to the growing number of international students entering business schools of "English-medium universities", but acknowledge a gap between the students' English proficiency and high employers' demands on graduates' communication skills. Andrade et al. also use the data of the Business Council of Australia to suggest that developing hard skills alone cannot ensure meaningful professional communication in English, and is unlikely to promote career success. This conclusion is supported by Chan, who in her article on workplace communication needs as perceived by Hong Kong senior executives also establishes a direct correlation between English proficiency coupled with high level of soft skills and successful career progress [7].

Another important conclusion made by Andrade et al. opens up some space for debate around the studied issue. While Rus and Medrea [5] give evidence of students' realizing the importance of developing English communication skills, the results of Andrade et al.'s study suggest otherwise: "Another concern is that views on the importance of English language skills differ between students and employers. According to the International Education Advisory Council, only one in five international graduates thought that English language competency was one of the most important skills that employers were looking for, while employers rated English language competency as one of the four key attributes" [8].

Such discrepancies among researchers regarding students' readiness to use English as a professional tool shows that this issue is still important to study, since English communication skills are among the top skills valued by employers and managers of international teams. Therefore, of particular importance and interest is the development of methods and techniques for training fresh university graduates who will meet the requirements of multinational enterprises to valuable foreign staff, and will be able to adjust to modern international human resource recruitment trends [9]. Those who research this area write about cross-cultural and communication barriers, that graduates from different countries have to overcome when they enter international business environment. They give examples of solving this problem through carefully planned pedagogical interventions using task-based, production-oriented and blended learning approaches[10, 11].

It is clear that such cooperation benefits not two, but three sides: business organizations, students and universities: «For the students that are involved in hands on international development work, applied experience is critical; for the NGOs/IGOs (Nongovernmental Organizations (NGOs) and Intergovernmental Organizations (IGOs)) and the communities they serve, such partnerships with University can supply vital resources, labor, and powerful learning outcomes for the students. Finally, for the universities entering these types of partnerships, the benefit is providing opportunities for their students that are high impact and experiential and meaningful» [12]. So, the literature review suggests that both employers and university staff are aware of the importance to make professional communication in English part of university curricula.

Despite being aware of the importance of English oral communication skills for successful teaching and learning in an increasingly globalized academic environment [13], as well as for effective interaction in multinational professional groups [14], Russian university EFL teachers face a lot of difficulties, when they teach professional communication skills to the students of non-linguistic majors. One of their most challenging tasks is to provide significant and sustainable improvement in dialogue-building skills needed for discussing professional issues in English.

We have already done extensive research into the reasons for this $[15,16]$, and will list only two most relevant ones:

1) dialogue skills are difficult to learn and practice in mixed-ability groups, because students with higher level of English proficiency tend to do all the talking;

2) most of the Russian non-linguistic universities teach English only in small groups with a fixed and permanent number of students (i.e., in small closed-type social groups).

Therefore, traditional classroom activities performed by a limited number of students according to limited curriculum content cannot prepare future graduates to real-life professional communication with its all its spontaneity and 
communicative, language and psychological barriers to building and maintaining dialogues in English. The survey included semi-closed questions concerning students' feelings, emotions, observations, and problems associated with English oral communication. Disregarding repetitions used to avoid bias, the survey focused on three main questions:

1) The preferred number of communication partners for the most convenient spontaneous communication (with answer options ranging from "None" to "Five or more").

2) Dominant feelings and emotions during conversations with strangers (with answer options including "Physiological discomfort", "Psychological discomfort", "Anxiety, fear or panic", "Curiosity", "Resentment", "Insecurity and selfdoubt", "Feeling the need to impress others", "Being sure of being misunderstood", and "Other").

3) The preferred topics for discussion, which in students' opinion ensure maximum communication effectiveness.

The obtained answers were used to develop the main principles for the second stage of the study, during which a pre-planned learning session was conducted. This stage implied establishing contact and communication between randomly chosen students from two universities (between Study Groups 1 and 2 using video recording technology. The third (final) stage took the form of a follow-up self-report survey, which helped to assess the students' readiness to continue interuniversity communication, and to adjust the next cycles of the study accordingly.

\section{RESULTS}

\section{A. Results of the First Stage of the Study}

The analysis of the most frequent answers showed that the majority of the study participants preferred speaking with maximum 3 people, because such conversations are easier to manage and keep track of. Only about $7 \%$ of respondents said that they would like to have discussions with 5 or more people. Many students said that talking to strangers causes physiological or psychological discomfort, and in the worst case scenario - anxiety, fear or even panic. Being asked about the preferred topic for discussion, the respondents chose discussing books, movies, television programs, questions specified by the curricula or their personal life experiences as the best possible ways to build a conversation. assessing students' noeds and commitment as well as their perception of learning effectiveness. In order to ensure concurrent validity, the preliminary questionnaires included reformulations of similar questions. The results of preliminary and post-learning surveys were compared between the study groups. All the study surveys were administered and assessed by the teachers of corresponding study groups with the help of Google Forms. This article will describe the procedures and results of the first part of the study, and will outline the planned activities for two remaining parts.

\section{Study Description}

During the first stage of the first study cycle, a preliminary survey was conducted among all four study groups in order to assess the participating students' willingness and readiness to communicate with strangers and to identify key 


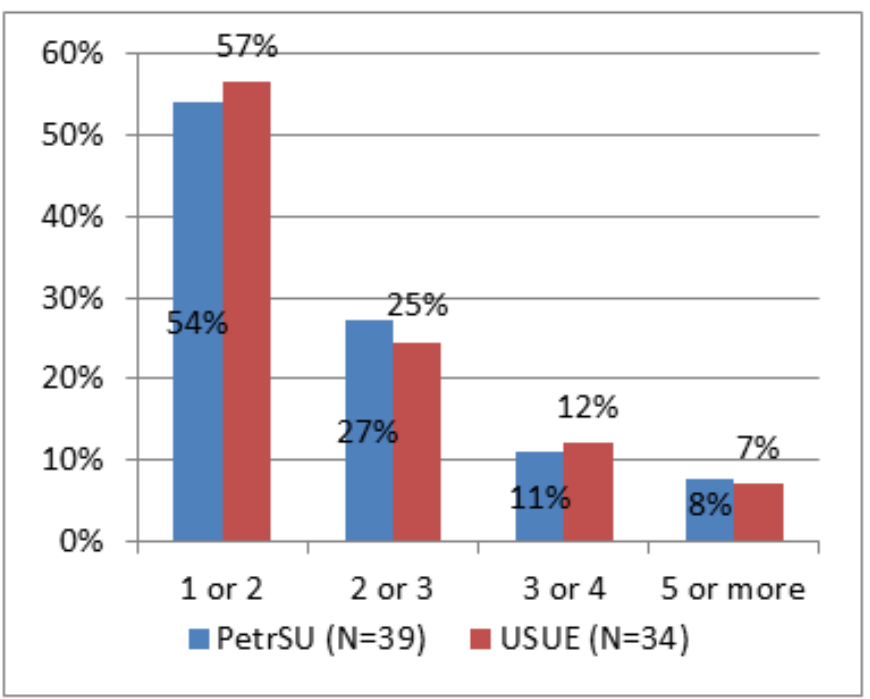

Fig. 1. The preferred number of communication partners

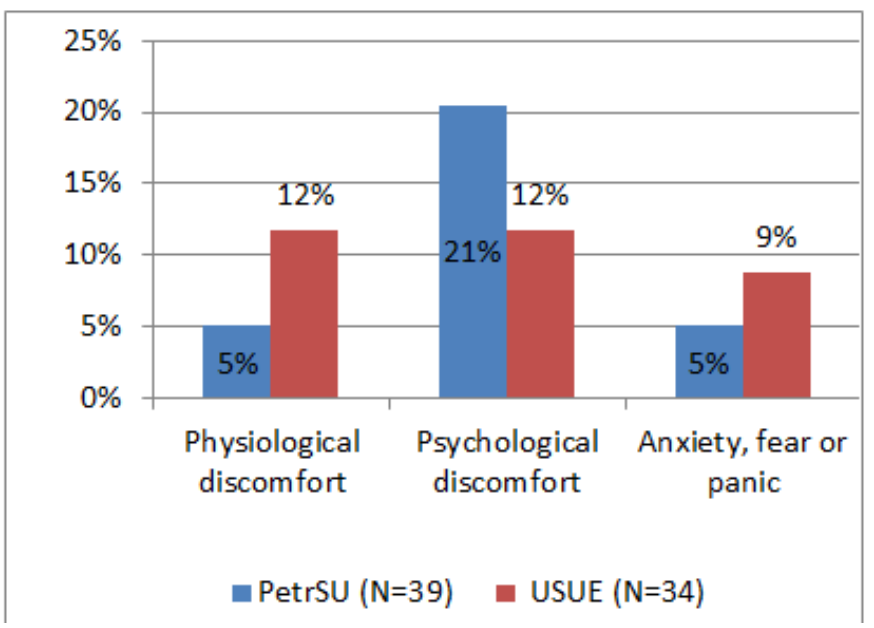

Fig. 2. The prevailing feelings caused by the necessity to talk to strangers

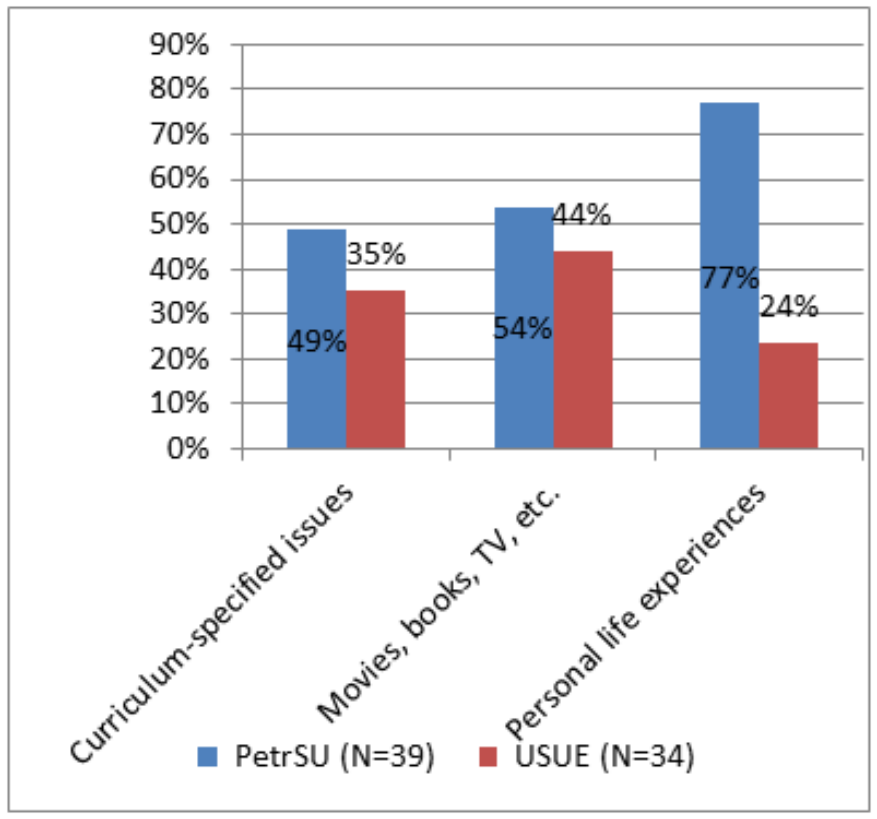

Fig. 3. The preferred topics for discussion

These answers suggested that they were ready to communicate, albeit with a very limited number of people, but at the same time, they are afraid of it and not quite ready for spontaneous conversations around professional topics. Having analyzed the results of the preliminary survey, we designed a learning activity model, which was likely to encourage students' communication and lower their anxiety without completely eliminating the surprise factor. The students were to exchange video recorded questions on two relatively simple topics ("My City" and "My Future Job") and upload video recorded answers to the questions randomly assigned to them to Google Disk. This format of work was called "briefing" and had a number of advantages from the point of future professional training: it imitates the process of building contacts in professional environment, and uses digital technology popular among professional teams.

\section{B. Results of the Second Stage of the Study}

Within one week the study participants made a list of open-ended questions, avoiding repetitions and making them professionally-oriented, if possible. The next week was spent assigning questions to the members of the opposite groups, video recording the answers and uploading them to Google Disk. In terms of professional training, this process took the students through some stages of a typical work project (gathering information, task assignment, work planning), and taught them basic project coordination and time management skills.

\section{Results of the Third Stage of the Study}

The follow-up survey conducted among the participants of the first "briefing" session showed that the majority of the students (93\% of USUE students and $82 \%$ of PetrSU students) gave positive feedback about this new format of learning. They said that such activity gives a chance to practice real-life 
English conversation skills, to overcome the fear of talking to strangers, and to prepare for communicating in English with other non-English speakers.

Some respondents were more specific in their feedback and mentioned that question-answer sessions with students from other universities can help to develop negotiation skills important for future career, to build logical chains for maximum clarity and relevance of answers, and to practice informal type of conversation (small talk) with strangers, which is considered an important skill for forming professional and personal relationships. The critical assessment of their work and its results helped the students reach an independent conclusion that expanding English vocabulary and mastering grammar will help them to minimize misunderstandings and maximize chances of being understood by a stranger. Besides, $24 \%$ of all the respondents stressed the importance of improving English pronunciation and intonation for lowering communication barriers. Many students expressed their willingness to move this interuniversity communication into more face-to-face and real-life settings. The participants' feedback will be incorporated into the design of the briefing sessions for the next stages of this longitudinal study. Possible ways for development may include increasing the number of participants, increasing spontaneity of inter-student communication, building contacts with more universities (including those from other countries), searching for more unconventional uses of technology, and making students' speaking tasks more professionally-oriented.

\section{DisCUSSION AND CONCLUSIONS}

Some modern scholars who analyze the structure of the communicative competence have been studying the impact of so-called "willingness to communicate" (WTC) [17, 18, 19, 20 ] on the effectiveness of communication in both native and foreign languages. The literature review suggests that strong self-esteem and high level of communication competence encourage people to communicate readily, and that if students are "confident about communicating in English, they tend to initiate English communication in both digital and offline settings" [21]. Therefore, the mechanism of such communication willingness among students with low level of communication competence requires further investigation.

The results of the follow-up survey showed that the students with relatively low English proficiency and communication confidence (USUE) were not only willing to communicate directly with the students from another university, but were ready to initiate the communication process. A number of researchers believe that the willingness to communicate in a foreign language is one of the key drivers for this language acquisition. Speaking about developing WTC and enhancing students' motivation to communicate, Öz, Demirezen and Pourfeiz stress the importance of building an appropriate learning environment: "Second language learners must be provided with more chances of strengthening their linguistic competence and communicative competence through increased opportunities for interaction... Therefore, it is the task of teachers to create anxiety-free atmosphere in the classroom for interaction through designing tasks that are cognitively less demanding and psychologically safer" [22] .

The experimental interuniversity "briefing" format tested during this study proved to be one of the safe and effective options to frame the following learning conditions:

1) establish more contacts to expand students' communication channels;

2) involve learners with different regional (or even national) background in order to expose them to real crosscultural communication;

3) create relatively stressful and challenging communication situations to build resilience;

4) reproduce certain specifics of professional interaction;

5) use modern communication technologies.

The preliminary research results lead to the conclusion that raising a new generation of professionals with soft skills and educational competence required by the new Russian economy is hardly possible without extending the range of teaching tools and changing approaches to teaching non-linguistic university students how to use a foreign language for professional communication.

\section{REFERENCES}

[1] T. H. Edwards, B. Ferrett, and D. Gravino, "Inter-firm R\&D collaboration within and across national borders", The World Economy, Accepted Author Manuscript, 18 October, 2019. DOI: https://doi.org/10.1111/twec.12894.

[2] N. M. Coe and H. W. Yeung, "Global production networks: mapping recent conceptual developments", Journal of Economic Geography, 2019, vol. 19, issue 4, pp. 775-801. DOI: https://doi.org/10.1093/jeg/lbz018.

[3] R. Minetti, P. Murro, Z. Rotondi, S.Ch. Zhu, "Financial Constraints, Firms' Supply Chains, and Internationalization", Journal of the European Economic Association, April 2019, vol. 17, Issue 2, pp. 327375, https://doi.org/10.1093/jeea/jvx056.

[4] O. Dmitrieva, T.Zmyzgova, E. Polyakova, "The system of continuous education as a decisive factor of personnel training for the digital economy", Advances in Economics, Business and Management Research, International Scientific-Practical Conference on Business Cooperation, ISPCBS 2019, 2019. vol. 90, pp. 130-134, https://doi.org/10.2991/ispcbc-19.2019.32.

[5] D. Rus and N. Medrea, "Developing Communicational Abilities in Professional Environments Through English Language Teaching", Procedia Economics and Finance, 2012, vol. 3, pp. 1161-1164. DOI: https://doi.org/10.1016/S2212-5671(12)00290-0.

[6] M. S. Andrade, K. J. Hartshorn, N. W. Evans, and Sh. Davis, "Good, better, Best: English language development practices in graduate business programs", The International Journal of Management Education, 2019, vol. 17, issue 1, pp. 36-46. DOI: https://doi.org/10.1016/j.ijme.2018.11.006.

[7] C. S. C. Chan, "Long-term workplace communication needs of business professionals: Stories from Hong Kong senior executives and their implications for ESP and higher education", English for Specific Purposes, 2019, vol. 56, pp. 68-83. DOI: https://doi.org/10.1016/j.esp.2019.07.003.

[8] M. S. Andrade, K. J. Hartshorn, N. W. Evans, and Sh. Davis, "Good, better, Best: English language development practices in graduate business programs", The International Journal of Management 
Results", Voprosy Obrazovaniya, Educational Studies Moscow, 2017 no. 3, pp. 132-151. DOI: 10.17323/1814-9545-2017-3-132-151.

Education, 2019, vol. 17, issue 1, pp. 36-46. DOI https://doi.org/10.1016/j.ijme.2018.11.006.

[9] H. Conrad, and H. Meyer-Ohle, "Overcoming the ethnocentric firm? foreign fresh university graduate employment in Japan as a new international human resource development method", The International Journal of Human Resource Management,_2019, vol. 30, issue 17, pp. 2525-2543. DOI: https://doi.org/10.1080/09585192.2017.1330275.

[10] K. Boonkita, "Enhancing the development of speaking skills for nonnative speakers of English", Procedia - Social and Behavioral Sciences, 2010, vol. 2, issue 2. pp. 1305-1309. DOI: 10.1016/j.sbspro.2010.03.191

[11] N. Martí and S. Fernández, "Telecollaboration and sociopragmatic awareness in the foreign language classroom", Innovation in Language Learning and Teaching, 2016, vol. 10, pp. 34-48, issue 1, DOI: https://doi.org/10.1080/17501229.2016.1138577.

[12] W. Haffar and S. Crenshaw, "International Collaborations and Global Engagement: NGOs/IGOs and Universities Looking to Make an Impact beyond the Classroom", University Partnerships for International Development, Innovations in Higher Education Teaching and Learning, Emerald Group Publishing Limited, 2016, vol. 8, pp. 77-91. DOI: https://doi.org/10.1108/S2055-364120160000008008.

[13] N. A. Caplan and S. G. Stevens, "Step Out of the Cycle": Needs, challenges, and successes of international undergraduates at a U.S. University", English for Specific Purposes, vol. 46, pp. 15-28. DOI: https://doi.org/10.1016/j.esp.2016.11.003,2017.

[14] J. Gasiorek and K. van de Poel, "Language-specific skills in intercultural healthcare communication: Comparing perceived preparedness and skills in nurses' first and second languages", Nurse Education Today, 2018, vol. 61, pp. 54-59. DOI: https://doi.org/10.1016/j.nedt.2017.11.008.

[15] I. Abramova and E. Shishmolina, "Modeling a Foreign-Language Environment When Teaching Non-Linguistic Students: Preliminary
[16] I. E. Abramova, "Communicative competence development through foreign language socialization of non-linguistic students", Perspectives of Science and Education, 2019, no. 4 (40), pp. 68-76. DOI: 10.32744/PSE.2019.4.6.

[17] N. Zarrinabadi and N.Tanbakooei, "Willingness to Communicate: Rise, Development, and Some Future Directions", Language and Linguistics Compass, 2016, vol. 10, issue 1, pp. 30-45. DOI: https://doi.org/10.1111/lnc3.12176.

[18] M. Al-Murtadha, "Enhancing EFL Learners' Willingness to Communicate With Visualization and Goal-Setting Activities", TESOL Quarterly, 2019, vol. 53, issue 1, pp. 133-157, DOI: https://doi.org/10.1002/tesq.474.

[19] J. E. Peng, L. Zhang, and Y. Chen, "The Mediation of Multimodal Affordances on Willingness to Communicate in the English as a Foreign Language Classroom", TESOL Quarterly, 2017, vol. 51, issue 2, pp. 302-331. DOI: https://doi.org/10.1002/tesq.298.

[20] R. P. Mil'rud and I. R. Maksimova, "Communicative competence as readiness of students to communicate in a foreign language", Language and culture, 2017, no. 38 , pp. 250-268. DOI: $10.17223 / 19996195 / 38 / 17$.

[21] J. Seong Lee and J. Chen Hsieh, "Affective variables and willingness to communicate of EFL learners in in-class, out-of-class, and digital contexts", System, 2019, vol. 82, pp. 63-73. DOI: https://doi.org/10.1016/j.system.2019.03.002.

[22] H. Öz, M. Demirezen, and J. Pourfeiz, "Willingness to communicate of EFL learners in Turkish context", Learning and Individual Differences, 2015, vol. 15, pp. 269-275. DOI: https://doi.org/10.1016/j.lindif.2014.12.009. 